\title{
WHY WRITE?
}

by Karin van Marle*

\section{Introduction}

How to respond to the question why write? And the question, I hasten to add, why read? And maybe the most pertinent one, why think? For me these questions are members of the same family, and like most if not all families live together in precarious and sometimes troubling ways. Writing, without reading and thinking, could end up in one of those over-simplified presentations of family life, falsely portraying the home as a one-dimensional, unreflective, necessarily safe and uncritical entity. However, as a diligent student I will keep to my task at hand and attempt a contemplation of the first question.

Why write if by writing we mean something more than to text, to email, to Google, to facebook? Why write if by living in a globalised world it seems as if access to the universe and everything that it offers is merely a tap on a keyboard away? Why write if the ultimate aim of everything is one of functionality or economic gain?

John Caputo tells us that "we have it from Aristotle that life is hard. ${ }^{1}$ According to Max Weber we live in a 'disenchanted' world. ${ }^{2}$ For Giles Deleuze 'What we most lack is a belief in the world, we've quite lost the world, it's been taken from us. ${ }^{3}$ Friedrich Nietzsche lamented the shift from a world where the ideal played a central role in human reflection to a world where empirical observation occupies a central place. ${ }^{4}$ However, as Nietzsche aptly observed, the shift away from the ideal world resulted in the disappearance of both ideal and real. ${ }^{5}$ Marianne Constable, following Nietzsche, has noted a similar shift in US legal theory, how through the years legal theory left a belief and interest in the ideal of justice behind to be replaced by nothing. ${ }^{6}$ One reason to start and keep writing is to respond to and

* Karin van Marle, Department of Legal History, Comparative Law and Legal Philosophy.

$1 \mathrm{~J}$ Caputo Radical hermeneutics. Repetition, deconstruction and the hermeneutic project (1987) 1.

2 M Weber 'Science as a vocation' in H Gerth and CW Mills (eds) From Max Weber: Essays in sociology (1946) 155.

G Deleuze Negotiations (1995) 176.

F Nietzsche Twilight of the idols (1968).

Nietzsche (n 4 above) 40-41.

M Constable 'Genealogy and jurisprudence: Nietzsche, nihilism, and the social scientification of law' Law \& Social Inquiry 193 (1994) 551-590. 
engage with the hardness of life, the disenchantment of the world, the loss of the ideal of justice. By this I am not suggesting writing as a redemptive project, but rather as a way of underscoring the complexities raised by the various philosophical perspectives, or as Caputo states, 'restoring life to its original difficulty.'

Most of you will probably not find the above a convincing argument - why write if it might result in further complication rather than simplification, why highlight problems if you can't solve them? The reason for writing that most practising lawyers and probably law teachers will support and that might convince students about the importance of writing is that as future lawyers, future legal scholars, your survival and success will depend on writing and particularly good writing. The lucidity of the office memorandums, letters, heads of argument, contracts and many other legal documents that you will draft will be of the utmost importance. Success or failure might depend on the strength of your legal research and argument, often presented orally, but always accompanied by a written document. Writing and more pertinently good writing will be part of and affect your future life as a lawyer.

Of course there is more to writing than the construction of a good sentence, the enumeration of correct headings and the drafting of legal documents, although all of this is important. Not only life is 'hard', good writing is hard as well. A certain way of writing of course could contribute to the 'disenchantment' of and the 'lack of belief' in the world, and the loss of justice on the one hand, but another way of writing on the other hand could respond to it, could open a gap, leave a trace of re-imagining, re-enchantment. Anthony Kronman, in a reflection on what he calls 'living in the law' argues as follows about what makes a good lawyer:

To achieve competence in the practice of law one must, of course, master a considerable body of doctrine and be familiar with the distinctive forms of argument the law employs. The truly distinguished lawyer, however, the one who is recognised by his or her peers in the profession as an exemplary practitioner and whose work is marked by subtlety and imagination, possesses more than mere doctrinal knowledge and argumentative skill. What sets such a lawyer apart and makes him a model for the profession as a whole is not how much law he [or she] knows or how cleverly he [or she] speaks, but how wisely he [or she] makes the judgments that his [or her] professional task require. When one lawyers wishes to praise the work of another, the compliment he is most likely to pay him is to say that he is a person of sound judgment. Nothing counts more among practicing lawyers than this. ${ }^{8}$ $861-862$ 
Kronman raises the concern that 'beyond a certain point ... the rationalisation of the law is likely to turn us all, those who teach the law as well as those who make and practice it, into bureaucratic functionaries, characterless experts whose work requires knowledge, precision, and fairness, but never judgment ...'.9 The concern with judgement might be one aspect that could shape our writing in such a way that it amounts to lawyers and legal scholars re-imagining and re-enchanting the world, to be more than 'legal slot machines.'10 South-African poet and writer, Antje Krog, in her latest book, Begging to be black states that in order for her to understand something she has to write it, and 'while writing - writingly as it were - I find myself dissolving into, becoming towards what I am trying to understand.'11 Following Krog writing then could assist you in obtaining better understanding.

For law students this would mean that you should write over and above the writing that you are doing as part of your LLB curriculum office letters, heads of arguments, essays or a final year dissertation. Write for the PSLR; write for the student news paper; start your own news paper or journal; write stories, poems, and songs. Turn the question 'why write?' into an embrace, an imperative, as a way of living in the law, but also as an attempt in making sense of living in the world.

$9 \quad$ Kronman (n 7 above) 876.

10 See 'Round and round the bramble bush: From Legal Realism to Critical Legal Scholarship' Harvard Law Review (1982) 957 1669-1690.

11 Krog Begging to be black (2009) 92. 